\title{
Building an Engineering Honors Curriculum: Collegiate Consistency with Individual Flexibility
}

Amy Brewster, UI College of Engineering, Robert Kirby, UI Honors Program, Art Spisak, UI Honors Program, Holly Blosser Yoder, UI Honors Program

\section{Introduction}

University-wide Honors programs typically have difficulties in making their own curricula accessible to students in the colleges or schools of Engineering. Professional colleges, such as Engineering, have disciplinary-specific core classes as well as a tight order of class sequence, which means that students may not have much flexibility in scheduling non-engineering courses. Also, engineering curricula, because of their strong focus on giving training in the discipline, often further restrict the range of general education classes required of their students (1). Yet, because Iowa's engineering students frequently meet the Iowa Honors Program entry requirements and the engineering curriculum here does push its students towards an honorsfriendly multidisciplinary approach, Honors and the College of Engineering were able to tailor a distinct University Honors curriculum for engineering students. It has flexibility via menu options, but it also allows for honors opportunities that are specific to no other college but Engineering.

\section{Development of an Honors Curriculum}

To develop a curriculum for Honors, information from four sources was gathered. The first were the guidelines established by the National Collegiate Honors Council, the international body that address honors education (2). The second was a review of our Peer Institutions honors curricular requirements. The third was a survey of recent graduates and what they felt was most useful about the program. The fourth was a review of how a cohort of freshman-through-senior honors students had used the program during the five-year period of 2008-2012. The information from these sources was then brought together to develop a curriculum that reflected current standards in honors education but "fit" the Honors student population and resources, as well as the University of Iowa as an institution.

Multiple strategies are being pursued to increase the participation of engineering students in Honors Programs. For example, some institutions have focused on building disciplinary-specific programs that focus on the junior and senior years (3). This strategy works especially well with pre-existing capstone experiences and departmental honors options. Institutions that have large engineering programs relative to the overall population often elect to have a collegiate specific Honors Program. An example would be Purdue University, which has both an Honors College and a College of Engineering Honors Program. The approach of Iowa to integrate the engineering honors with the University Honors Program is shared with our sister institution Iowa State University (4). This allows students to gain from university-wide opportunities and interactions with peers across the academic disciplines while still benefiting from the in depth disciplinary experiences uniquely available in their college. 
Honors at Iowa serves students in all the undergraduate degree granting colleges of the University. At the University of Iowa, the majority of undergraduates are in the College of Liberal Arts and Sciences (76\%). Undergraduates in the College of Engineering comprise only $11 \%$ of the undergraduate population. The other professional colleges also represent a fairly small percent of the undergraduate population. While the percent of undergraduates in these colleges is lower than the percent in the College of Liberal Arts and Sciences, the professional colleges have a slightly higher percent of their students as members of the University Honors Program. For example, 16\% of the undergraduates in Engineering are members of University Honors while only $12 \%$ of the overall undergraduate population are University Honors students. Because honors serves such a disciplinarily diverse population of students, two key features were woven into the development of the Honors curriculum - consistency and flexibility. Consistency was maintained so that all students irrespective of major or college were being recognized for similar levels of commitment to their honors education. Flexibility was maintained to recognize that honors-worthy experiences varied by individual student as well as by disciplines of study.

\section{University Honors Curriculum $12+12$}

In 2013, the University of Iowa Honors Program implemented a new curriculum in order to provide its students with a well-defined sense of what it means to be an Honors student at Iowa, and also to give honors recognition on transcripts and diplomas. The new curriculum required a combination of honors coursework and experiential learning. Specifically, it required coursework totaling 12 semester hours of honors credit plus experiential learning from a menu of options such as honors in the major, research, internships, or study abroad, also totaling 12 semester hours of honors credit (or program-certified equivalents). Essentially, the Honors Program is now requiring and officially rewarding what the most successful honors students had done, but had only been recommended before.

The expectation was that more honors students would take more honors general education courses as a result of the new requirement, an opportunity believed to benefit them. And, to meet the demand, Honors would offer more sections of general education courses such as Rhetoric, Intro to Psychology, Principles of Chemistry and others.

\section{Engineering Alternative $6+18$}

The College of Engineering welcomed the idea of honors requirements, but it was concerned that Engineering students might have a difficult time meeting the 12 semester-hour coursework requirement because their schedules are more firmly tied to engineering-specific requirements and therefore have less room for the types of general education courses Honors normally requires. They wanted to require some honors coursework, but less than the full 12 credit hours required by the standard University Honors curriculum. Rather than an even 12/12 split between coursework and experiential learning, it made sense to adapt the honors requirements to allow for a heavier emphasis on experiential learning, and especially since Engineering puts a premium on experiential learning. Through a series of meetings and negotiations, Honors and Engineering developed an Engineering alternative curriculum that allowed for a 6/18 split between coursework and experiential learning. 
To enrich the Level II Experiential Learning possibilities for its students, Engineering added to the existing options already identified by the Honors Program. Advisors identified a menu of experiential learning options specific to the College of Engineering that they considered a good fit for talented students and enhanced the educational experience of their students within their field of study. In addition to honors in the major, research, study abroad and internships, engineering students could now earn honors credit for a new set of experiences, known as Engineering Community Engagement Experiences. These experiences were specifically chosen by Engineering's own educators and advisors, and then were approved by the Honors staff. The selection of these experiences represented the College of Engineering's commitment to improving undergraduate education by encouraging research involvement, one-on-one interactions between students and faculty, working in teams, and gaining professional experiences as suggested by ABET (5).

\section{Engineering Community Engagement Experiences}

Each item in the list below represents an area of Engineering Community Engagement that students can use in limited amounts towards University Honors. Students may earn two honors credits per semester of involvement for any of the listed experiences up to a maximum of 10 credits with no more than 4 from a single area.

\section{Engineering Teaching Assistant (TA)}

Teaching Assistants work under the direction of a faculty member. Typical responsibilities include: assisting students through one-on-one meetings, grading assignments, and holding office hours. Where lab work is involved, Teaching Assistants might also be responsible for keeping the equipment in working order, helping students understand lab content, and grading laboratory reports.

\section{Engineering Tutor}

The College of Engineering offers free walk-in tutoring to all engineering students for most engineering, math, and science courses required during the first three semesters of study. Engineering Tutors assist students in gaining knowledge and insight about the learning process and also promote independence in learning. Tutoring typically takes place in small groups.

\section{$\underline{\text { Hanson Center for Technical Communication Peer Consultant }}$}

The Hanson Center for Technical Communication offers engineering students a comprehensive resource for developing communication skills as part of their engineering education. Peer Consultants engage with engineering students as they work on a wide range of assignments, from lab reports and term papers to PowerPoint slides and scholarship statements. Peer Consultants address global concerns (organization, clarity, and relevant analysis) and help fellow students turn rough drafts into professional reports and proposals. 
A leadership role in an Engineering student organization

A leadership role in an Engineering student organization can take on many forms due to the large number and type of student organizations available to students. Students seeking honors credit for this type of experience must serve as an officer for their student organization and coordinate a major project or function for the organization.

\section{Engineering Student Ambassador}

Students in this role assist in activities to recruit prospective engineering students. They are involved in organizing and participating in activities for prospective students, contacting prospective students via e-mail and postcards, organizing and implementing college events, and arranging student panels.

\section{Engineering Peer Advisor}

Six fourth-year students are selected to serve as Peer Advisors each year-one from each academic major offered in the College of Engineering. Peer Advisors work in the Student Development Center to provide support to first-year and transfer students. Peer Advisors apply personal experiences to help students build balanced course schedules relative to their academic and personal needs. They provide information related to courses, registration, and procedures. They also create and facilitate workshops to teach students undecided in their plan of study about their academic major.

Students document completion of an Engineering Community Engagement experience through a verification form. On the form, students are expected to provide general information about their engagement experience, including the name and signature of their supervisor. Students are also asked to provide a 200-400 word reflection on the experience, in which they articulate what they gained from the experience, as well as how the experience enhanced their undergraduate experience as an honors student. Completed Engineering Community Engagement Experiences are then noted in the students' official academic record as part of their work towards University Honors that is recognized on the transcript and diploma.

\section{Promotion of University Honors within the College of Engineering}

The College of Engineering is committed to the Engineering Alternative option for engineering students to earn University Honors. Amy Brewster, Director of Global Experiences and Academic Advisor within the College of Engineering, serves as liaison to the University Honors Program. She coordinates college-specific efforts to promote participation in University Honors. For example, a college-sponsored brochure about honors education opportunities is distributed to prospective students when they visit campus. Students newly-admitted to the College of Engineering learn about benefits of participating in University Honors during first-year, transfer, and international student orientation sessions. University Honors is also highlighted on the College of Engineering Web site, and faculty are kept informed about University Honors through visits to departmental faculty meetings. 


\section{Engineering Honors Curriculum: Student Impact}

Students were first able to graduate with University Honors during the 2013-2014 academic year. There were 25 undergraduates in the College of Engineering who graduated with University Honors. Of these, 10 graduated with departmental Honors. These numbers should rise substantially in the next few years because these requirements were in place for the 2013-2014 graduates only in their senior year. To a large degree, they met the requirements out of their own educational commitment. The Honors Engineering curriculum has now become a standard part of advising for engineering students and all entering high ability students learn about these opportunities and their benefits from the beginning of their undergraduate career.

To get a perspective on how the new curriculum benefits engineering students, graduating seniors' thoughts on the value of honors were solicited. Several common themes were found among the seniors responses. The first was in the area of being challenged by the requirements. As one student put it:

My attempts to gain the honors credits pushed me to try things I do not think I would have been brave enough to try on my own. I found that it challenged me in great ways that helped me develop myself both personally and professionally, not to mention the great sense of accomplishment you get out of it in the end. Having gone through with all these various experiences helped me be a well-rounded individual. A fact that did not go unnoticed when the time came to apply for jobs. Many employers were quite impressed with the various fields I was exposed to and especially the experiences gained from them.

The theme of challenge was found to apply at multiple levels, including the honors classroom experience, where it tied into the benefits of meeting peers. Of the honors coursework requirement, one of the seniors said:

I was challenged in a positive way in the classroom, but encouraged throughout by the support of my professors. I also met and became friends with equally intelligent classmates with whom I shared common goals and interests. The honors program provided me with a platform to meet students who shared similar interests, were equally ambitious, and became good friends! You are more engaged and stretched in your classes and have the benefits of maximizing your academic potential.

In addition to enriching the intellectual challenge of the College of Engineering experience and developing connections with their peers and professors, the experiential nature of the curriculum also prepared students to move beyond their undergraduate degree:

Participating in Engineering Honors opened my eyes to a field of biomedical engineering that I had limited exposure to prior to the project. It also introduced me to the academic research setting as my prior experiences had been with research and development in industry.

Or, as another student said:

Participating in honors has been a really great experience for me. It has challenged me and helped me find something that I really love to do. Completing an honors thesis has been a fantastic experience, and has prepared me for graduate-level work. I really 
enjoyed this experience and because of it, I've chosen to focus my Ph.D. on orthopedic tissue engineering ....

The themes of challenge, building connections, and preparation for the future come through clearly in the students' comments and were primary themes build into the Honors curriculum.

\section{Conclusion}

The Honors Program and College of Engineering over a period of a year worked to develop a distinct honors engineering curriculum. This engineering-specific honors curriculum incorporated the key features of course work and experience-based learning valued by Engineering and Honors, but also incorporated unique out-of-class experiences available to University of Iowa engineering students. The result of this collaboration between Honors and the College of Engineering is an honors engineering curriculum that meets the general requirements of the Honors curriculum as applied across all the undergraduate colleges but also is flexible enough to accommodate the more structured and sequential nature of the engineering curriculum.

\section{Acknowledgments}

The authors thank Kelli Delfosse and Keri Hornbuckle from the College of Engineering for their valuable contributions in the development of the Honors Engineering Alternative curriculum.

\section{References}

1. Giazzoni, M., The Fessendon Honors in Engineering Program. Honors in Practice, 3, 7981 (2007).

2. Schuman, S., Beginning in Honors: A Handbook. National Collegiate Honors Council Monograph Series, Paper 7 (2006).

3. Pohlman, N.A., Ghrayeb, O., and Vohra, P., Developing a disciplinary honours programme within an engineering college. Global Journal of Engineering Education, 14, 1, 20-26 (2012).

4. Yager, S., Kaleita-Forbes, A., and Miller, J., A Three-Pillar Approach to Honors in an Engineering College, National Collegiate Honors Council, Annual Conference, 2014.

5. Educating the Engineer: Adapting Engineering Education to the New Century. The National Academies Press (2005). 


\section{Tables}

\section{Table 1. University Honors Engineering Alternative}

A. These requirements apply to all Engineering students regardless of when they enter the Honors Program. Half the 24 credits (12) must be completed within 6 semesters of full-time registration as an Honors student (with the exception of the Grand Challenges Program), and 6 of the 24 hours must be honors coursework.

B. All Honors admits must take an honors course in the first semester in the program

C. Students satisfy the 24 credit requirement through the following options or combination of options:

1. Engineering Grand Challenges Scholars Program

- completely satisfies the University Honors requirements for Engineering students

2. Honors coursework (including graduate coursework)

- may apply a maximum of 12 semester hour credits

3. Mentored research

- may apply a maximum of 12 credits (10 hrs/wk for a semester $=3$ credits)

- Summer semester research at 20 hrs/wk counts as 6 credits

4. Study abroad for one semester (fall or spring) or the equivalent time in summer and between-semester experiences $=6$ credits

- all study abroad requires students to carry out an independent project while abroad and to conduct a poster presentation or write a report on the project

- may apply a maximum of 12 credits

5. A registered internship or co-op

- $40 \mathrm{hrs} / \mathrm{wk}$ for 15 weeks (one semester or the equivalent time in summer and betweensemester experiences) $=6$ credits; 20 hrs $/ \mathrm{wk}=3$ credits

- 40 hrs/wk for 10 weeks (summer internships) $=4$ credits; 20 hrs $/$ wk $=2$ credits

- may apply a maximum of 12 credits

- students are required to register their internship with the College and meet the College requirements for reporting and evaluation

6. An Engineering community engagement experience

- See http://www.engineering.uiowa.edu/ess/honors for the Engineering Community Engagement Experience Verification form, required to have these experiences count as honors credits

- may apply a maximum of 10 credits from all these experiences, no more than 4 from a single area

- each experience listed below counts as 2 credits per semester

(a) A leadership role in an Engineering student organization

(b) Engineering Teaching Assistant

(c) Hanson Center for Technical Communication Peer Consultant

(d) Engineering Tutor

(e) Engineering Student Ambassador

(f) Engineering Peer Advisor

7. Honors in the major - counts as 12 credits 